\title{
Complementary and alternative medicine use by patients chronically infected with hepatitis $C$ virus
}

\author{
Colin P White BSc ${ }^{1}$, Gerilynn Hirsch NP${ }^{1}$, Sunil Patel $M D^{1}$, Fatin Adams $\mathrm{MD}^{2}$, Kevork M Peltekian $M D^{1}$
}

CP White, G Hirsch, S Patel, F Adams, KM Peltekian. Complementary and alternative medicine use by patients chronically infected with hepatitis $C$ virus. Can J Gastroenterol 2007;21(9):589-595.

Complementary and alternative medicine (CAM) is becoming increasingly popular in North America. The use of CAM is also popular in patients with chronic liver disease but is not well documented. The extent of use of CAM in chronic hepatitis $\mathrm{C}$ virus (HCV) infected patients was determined, and the demographic and clinical data between users and nonusers of CAM was compared.

Seventy-six patients ( $30 \%$ female) with chronic HCV were interviewed. The mean age was $43 \pm 8$ years. Current use of CAM for HCV was reported by 35 of 76 patients (46\%). Eighteen of 76 patients within this group used herbal supplements (24\%). The most commonly used herb was Silybum marianum (milk thistle), reported by 10 of 76 patients (13.2\%). Commonly reported benefits of CAM use included reduction in fatigue, boost in the immune system and improved gastrointestinal function. No adverse effects of CAM use were reported. In the present study, four of 18 patients (22\%) with chronic liver disease taking herbal therapies were on herbs that increased bleeding time.

The use of CAM in chronic HCV patients is significant. Patients should be asked specifically about their use of CAM. CAM use may have implications affecting conventional treatment and management of HCV.

Key Words: Ambulatory care; Complementary and alternative medicine; Herbal therapy; Milk thistle; Nova Scotia; Nurse practitioner; Questionnaire; Viral hepatitis

Complementary and alternative medicine (CAM) is Uincreasing in usage and popularity across North America (1). In the United States, the rates of CAM use among the general population have risen from $34 \%$ in 1991 to $42 \%$ in 1997 (2). In Canada, the rates of CAM use have risen from $33 \%$ in 1997 to $43 \%$ in 1999 among patients with inflammatory bowel disease (IBD) (3). CAM includes use of natural health products such as vitamins, homeopathic remedies, traditional therapies and herbal medicines (4). In a recent literature review (5), over $50 \%$ of patients that required health care used CAM either in conjunction with, or separate from, conventional health care.

\section{Les approches complémentaires et parallèles en santé qu'utilisent les patients atteints d'une infection chronique par le virus de l'hépatite $\mathrm{C}$}

Les approches complémentaires et parallèles en santé (ACPS) sont de plus en plus populaires en Amérique du Nord. Le recours aux ACPS est également populaire chez les personnes atteintes d'une maladie hépatique chronique, mais est mal documenté. On a déterminé à quel point les personnes atteintes d'une infection chronique par le virus de l'hépatite $\mathrm{C}$ (VHC) utilisent les ACPS et comparé les données démographiques et cliniques entre les utilisateurs et les non-utilisateurs.

On a interrogé 76 patients ( $30 \%$ de femmes) atteints d'une infection chronique par le VHC, d'un âge moyen de $43 \pm 8$ ans. Trente-cinq des 76 patients (46\%) utilisaient les ACPS pour soigner leur VHC, dont 18 (24\%) des plantes médicinales. La plante la plus utilisée était le Silybum marianum (charbon Marie), dix des 76 patients (13,2\%) y faisant appel. Les bienfaits courants des ACPS souvent déclarés étaient la réduction de la fatigue, la stimulation du système immunitaire et l'amélioration de la fonction intestinale. Les patients n'ont déclaré aucune réaction indésirable attribuable aux ACPS. Dans la présente étude, quatre des 18 patients ( $22 \%)$ atteints d'une maladie hépatique chronique qui prenaient des plantes médicinales avaient choisi des plantes qui accroissaient la durée des saignements.

De nombreuses personnes atteintes d'une infection chronique par le VHC utilisent des ACPS. Il faut demander aux patients s'ils utilisent des ACPS, car celles-ci peuvent influer sur le traitement et la prise en charge classiques du VHC.

${ }^{1}$ Hepatology Services, Division of Gastroenterology, Departments of Medicine, Dalhousie University and the Capital District Health Authority,

Halifax, Nova Scotia; ${ }^{2}$ Rockyview General Hospital, Calgary, Alberta

Correspondence and reprints: Dr Kevork M Peltekian, Atlantic Hepatology, P.O. Box 60010, Halifax, Nova Scotia B3H 4 R7.

Telephone 902-473-2898, fax 902-473-2783, e-mail Kevork.Peltekian@dal.ca

Received for publication September 16, 2006. Accepted January 26, 2007 
There is ample literature examining CAM use in chronic diseases, such as $\operatorname{IBD}(3,9,10)$, but it is sparse regarding liver disease and specifically hepatitis C virus (HCV). In one study (11) involving liver disease and CAM, up to $39 \%$ of patients attending liver disease clinics admitted to using some form of CAM at least once during the preceding month. The average use of CAM in liver disease patients was reported to be $41 \%$ (range $33 \%$ to $75 \%$ ) in a study involving six different institutions (12). A study in Florida (13) showed $43 \%$ of patients who used CAM used it for liver disease. One study that specifically surveyed clinic patients (14) found that of $37 \%$ of patients that had used or were using CAM, 20\% were using the CAM therapy because of chronic hepatitis and $17 \%$ were using it for other reasons. The use of CAM for liver disease may actually be higher outside western populations; a study (15) looking at CAM use in Taiwanese patients found as many as $66 \%$ of patients used CAM.

$\mathrm{HCV}$ is a serious worldwide problem. In Canada, the current mortality figures may double in the next 10 years (16). We know there is a general use of CAM in Canada but its use in liver disease, specifically HCV, is unknown.

\section{METHODS}

\section{Participants}

Patients were recruited from the viral hepatitis clinic at the Queen Elizabeth II Health Sciences Centre in Halifax, Nova Scotia. The clinic is run using a collaborative model, and includes a nurse practitioner and hepatologist. It serves the greater Halifax Regional Municipality and most of Nova Scotia. Annually, approximately 200 new HCV-infected patients are referred there. They receive over 1000 clinic visits by HCV-infected patients each year. All attending the clinic were eligible to participate in the study. Over a three-week period, the CAM Questionnaire (Appendix) was incorporated into the routine interview of patients seen in the clinic by the nurse practitioner or physician.

\section{Data collection}

The questionnaire created for the study was similar to other published surveys of CAM use (10). Data were gathered on patient demographics, education and annual household income. Patients were also asked which symptoms associated with HCV they experienced. Characteristics of each patient's liver disease, conventional HCV treatment used (interferonbased regimens), the current use and perceived effects of CAM, vitamin supplements, prescription drugs and over-thecounter medications were also reviewed (Appendix).

\section{Statistical analysis}

Descriptive statistics (mean, SD, range and proportions) were used to describe each variable. All variables were entered into multivariate regression to identify independent associations with the use of either CAM or herbal therapies. The strength of association between variables was measured with OR and associated 95\% CI. Statistical significance was demonstrated by CIs that did not include unity, or by a $\mathrm{P}<0.05$ calculated using the Student's $t$ test. Statistical analysis was performed using Minitab software version 14 (Minitab Inc, USA).

\section{RESULTS}

\section{Demographics of the sampled population}

The characteristics of the 76 patients with chronic HCV who completed the questionnaire are summarized in Table 1.
Twenty-three were women (30\%) and 53 were men (70\%). The mean age of the study participants was $43 \pm 8$ years (range 25 to 66 years). The education levels varied throughout the sampled population. Twenty-nine patients (38\%) had high school education, $32(42 \%)$ had post secondary education and $15(20 \%)$ had college or university education. The annual household income was less than $\$ 15,000$ in 33 patients (43\%) and greater than $\$ 45,000$ in 19 patients $(25 \%)$.

Symptoms experienced by patients were reported as being either present or absent. The symptoms could be caused by the $\mathrm{HCV}$, side effects of medications or by other concurrent pathologies. Fatigue was reported by 52 patients (68\%), and irritability was reported by 20 patients $(26 \%)$. Headaches were reported by 22 patients $(29.0 \%)$, while arthralgia was reported by 16 patients $(21 \%)$. Nausea, right upper quadrant pain, myalgia and anorexia were reported by 12 (16\%), 20 (26\%), 12 (16\%) and six $(8 \%)$ patients, respectively. The prevalence of these symptoms was comparable to frequencies that were recently published by researchers identifying symptom clustering in HCV-infected subjects (17).

Twenty patients $(26 \%)$ had either been or were on a combination of alpha-interferon and ribavirin. Forty-one patients (54\%) were taking one or more prescribed medications for treatment of diseases other than HCV. These included anxiolytics and antidepressants, thyroid replacements, bronchodilators and antihypertensive medications.

\section{HCV-related liver disease descriptions}

All 76 patients tested positive for HCV by polymerase chain reaction. The average time from diagnosis of $\mathrm{HCV}$ was 3.8 years (range one to 10 years). Mean liver enzyme counts were: $81 \pm 33 \mathrm{U} / \mathrm{L}$ for alkaline phosphatase, $79 \pm 58 \mathrm{U} / \mathrm{L}$ for alanine aminotransferase, $62 \pm 54 \mathrm{U} / \mathrm{L}$ for aspartate aminotransferase and $156 \pm 205 \mathrm{U} / \mathrm{L}$ for gamma-glutamyl transpeptidase.

Liver function tests for total bilirubin averaged $13 \pm 5 \mu \mathrm{mol} / \mathrm{L}$. Albumin averaged $42 \pm 7 \mathrm{~g} / \mathrm{L}$ and international normalized ratio (INR) for prothrombin time averaged 1.0 \pm 0.2 .

Liver biopsy had been performed in 48 patients (63\%). According to the METAVIR fibrosis staging system, three patients $(6 \%)$ had no fibrosis (stage 0$)$, five $(10 \%)$ had stage 1, $18(38 \%)$ had stage 2, $11(23 \%)$ had stage 3 and $11(23 \%)$ had cirrhosis (stage 4$)$.

\section{CAM therapies}

Current CAM use was reported by 35 of 76 patients $(46 \%)$. CAM use included the use of vitamins or minerals, herbal supplements or NST. Use of CAM among the 20 patients on antiviral therapy was significantly higher than use among other patients $(58 \%, \mathrm{P}=0.117)$.

The overall satisfaction level for all types of CAM use was very high. No patients reported that any of the CAM therapies worsened their condition. Seventeen of 28 (61\%) CAM users commented that therapy use left their condition unchanged. Six users $(21 \%)$ felt the therapy made them better and five users $(18 \%)$ believed CAM use made them significantly better.

Qualitative perceived effects of CAM use included eight of 20 respondents $(40 \%)$ commenting that the CAM therapy either had no effect or they were not sure of any change. Three respondents (15\%) said their current use of CAM therapy improved or was good for their immune system. Six (30\%) said 
TABLE 1

Summary of patient population characteristics

\begin{tabular}{|c|c|}
\hline Characteristic & \\
\hline \multicolumn{2}{|l|}{ Sex } \\
\hline Male & $53(70)$ \\
\hline Female & $23(30)$ \\
\hline Age, years & $43 \pm 8(25-66)$ \\
\hline \multicolumn{2}{|l|}{ Education } \\
\hline High school & $29(38)$ \\
\hline Post secondary & $32(42)$ \\
\hline College or university & $15(20)$ \\
\hline \multicolumn{2}{|l|}{ Household income: } \\
\hline$<\$ 15,000$ & $33(43)$ \\
\hline$\$ 15,000-\$ 30,000$ & $10(13)$ \\
\hline$\$ 30,000-\$ 45,000$ & $14(18)$ \\
\hline$\$ 45,000-\$ 75,000$ & $14(18)$ \\
\hline$>\$ 75,000$ & $5(7)$ \\
\hline \multicolumn{2}{|l|}{ Symptoms } \\
\hline Fatigue & $52(68)$ \\
\hline Headache & $22(29)$ \\
\hline Right upper quadrant pain & $20(26)$ \\
\hline Irritability & $20(26)$ \\
\hline Arthralgia & $16(21)$ \\
\hline Nausea & $12(16)$ \\
\hline Myalgia & $12(16)$ \\
\hline Anorexia & $6(8)$ \\
\hline \multicolumn{2}{|l|}{ HCV descriptions } \\
\hline HCV PCR positive & $76(100)$ \\
\hline Time from diagnosis of HCV (years) & $3.8 \pm 2.7(1-10)$ \\
\hline Undergone liver biopsy & $48(63)$ \\
\hline \multicolumn{2}{|l|}{ Stage of liver fibrosis by METAVIR } \\
\hline Stage 0 & $3(6)$ \\
\hline Stage 1 & $5(10)$ \\
\hline Stage 2 & $18(38)$ \\
\hline Stage 3 & $11(23)$ \\
\hline Stage 4 & $11(23)$ \\
\hline \multicolumn{2}{|l|}{ Complete blood count } \\
\hline WBC & $6.0 \pm 2.0(2.0-11.2)$ \\
\hline Hemoglobin (g/L) & $143 \pm 15(111-176)$ \\
\hline Platelet count & $201 \pm 71(43-417)$ \\
\hline \multicolumn{2}{|l|}{ Liver enzymes } \\
\hline Alkaline phosphatase (U/L) & $81 \pm 33(35-232)$ \\
\hline Alanine aminotransferase $(\mathrm{U} / \mathrm{L})$ & $79 \pm 58(15-408)$ \\
\hline Aspartate aminotransferase $(\mathrm{U} / \mathrm{L})$ & $62 \pm 54(13-345)$ \\
\hline Gamma-glutamyl transpeptidase (U/L) & $156 \pm 205(25-916)$ \\
\hline \multicolumn{2}{|l|}{ Liver function tests } \\
\hline Total bilirubin $(\mu \mathrm{mol} / \mathrm{L})$ & $13 \pm 5(4-35)$ \\
\hline Albumin $(\mathrm{g} / \mathrm{L})$ & $42 \pm 7(14-77)$ \\
\hline International normalized ratio & $1.0 \pm 0.2(0.8-1.5)$ \\
\hline \multicolumn{2}{|l|}{ Treatments } \\
\hline Patients on prescribed medications not for $\mathrm{HCV}$ & $41(54)$ \\
\hline Patients on specific therapies for $\mathrm{HCV}$ & $26(34)$ \\
\hline Patients on CAM therapies & $35(46)$ \\
\hline
\end{tabular}

Units expressed in $n$ (\%) or mean $\pm S D$ (range). CAM Complementary and alternative medicine; HCV Hepatitis C virus, PCR Polymerase chain reaction, WBC White blood cells
TABLE 2

Complementary and alternative medicine use

\begin{tabular}{lc}
\hline Vitamin or mineral supplements, $\mathrm{n}=21$ & $17(81)$ \\
Multiple or single vitamins & $7(33)$ \\
Minerals & $2(10)$ \\
Selenium & $1(5)$ \\
Beta-carotene & \\
Herbal supplements, $\mathrm{n}=18$ & $10(56)$ \\
Milk thistle & $3(17)$ \\
Evening primrose oil & $2(11)$ \\
Glucosamine supplements & $2(11)$ \\
Ginseng & $1(6)$ \\
Licorice & $1(6)$ \\
Dandelion & $1(6)$ \\
Echinacea & $1(6)$ \\
Ginkgo biloba & $5(28)$ \\
Other (barley green, lutein, grape & \\
seed, alfalfa, garlic) & \\
Natural self treatments, $\mathrm{n}=14$ & $8(57)$ \\
Meditation & $8(57)$ \\
Acupuncture & $4(29)$ \\
Prayer & $1(7)$ \\
Massage & $1(7)$ \\
Aromatherapy & $8(57)$ \\
Other (exercise, relaxation, & \\
wellness programs, group counselling) & \\
\hline Unit expressed in $n$ (\%) &
\end{tabular}

Units expressed in $n$ (\%)

the therapy reduced fatigue or increased energy, and two (10\%) said CAM made them psychologically better or more at peace. Most of the 25 patients using CAM therapy reported spending less than $\$ 50$ per month on CAM. Only one patient (4\%) was spending $\$ 50$ to $\$ 100$ per month on CAM.

Twenty-one of 76 patients (28\%) used vitamin or mineral supplements (Table 2). This category included one patient $(5 \%)$ using beta carotene, 17 patients $(81 \%)$ on multi- or single vitamins, two patients (10\%) on selenium and seven patients (33\%) on mineral supplements. Twenty patients took vitamin or mineral supplements for an average period of 16 months. Of these patients taking vitamins, minerals or oils, one patient (5\%) took them for three months, eight patients $(40 \%)$ for six months, four patients (20\%) for 12 months, four patients (20\%) for 24 months, two patients (10\%) for 36 months, and one patient (5\%) for 48 months.

The patients taking herbal supplements totalled 18 of $76(24 \%)$. There was no difference in use of herbal supplements between those subjects on antiviral therapy for HCV (27\%) and those naïve to HCV therapy (20\%), P=0.521. The most frequently used herbal supplement was milk thistle, used by 10 of 18 patients (56\%). Seventeen patients took herbs for an average period of four months. Of these patients taking herbal supplements, three patients (18\%) had taken them for one month, two patients (12\%) for two months, nine patients $(53 \%)$ for three months, one patient $(6 \%)$ for four months, one patient $(6 \%)$ for five months, and one patient $(6 \%)$ for 24 months. 


\begin{tabular}{|c|c|c|c|}
\hline Variable & Coefficient ( \pm SE) & Odds ratio $(95 \% \mathrm{Cl})$ & $\mathbf{P}$ \\
\hline \multicolumn{4}{|l|}{ For CAM use } \\
\hline Albumin & $0.054 \pm 0.039$ & 1.06 (0.98 to 1.14$)$ & 0.165 \\
\hline Education level & $0.65 \pm 0.34$ & 1.92 (0.99 to 3.70$)$ & 0.053 \\
\hline \multicolumn{4}{|c|}{ For herbal therapy use } \\
\hline Headache & $1.86 \pm 0.71$ & 6.40 (1.60 to 25.52$)$ & 0.009 \\
\hline Education level & $0.79 \pm 0.40$ & 2.21 (1.02 to 4.80$)$ & 0.045 \\
\hline Arthralgia & $1.08 \pm 0.83$ & $0.34(0.07$ to 1.73$)$ & 0.193 \\
\hline Anorexia & $1.50 \pm 1.24$ & $0.22(0.02$ to 2.53$)$ & 0.225 \\
\hline
\end{tabular}

While 13 of 18 patients (72\%) reported using a single type of herbal supplement, three patients $(17 \%)$ reported combining two herbal supplements and another two patients (11\%) reported taking three types of supplements at the same time. The most common source of herbal supplements was a pharmacy or grocery store $(83 \%, 15$ patients). Only three patients $(17 \%)$ reported obtaining herbal therapy directly from an alternative therapy practitioner.

The majority of patients $(68 \%, \mathrm{n}=17)$ taking herbal, vitamin or mineral supplements reported nutrition/supplement stores as their main sources of knowledge or information for CAM therapies. The Internet was the main source for four patients (16\%), books for two patients (8\%), alternative medicine practitioner for one patient $(4 \%)$ and a specialist for one patient (4\%). No patients reported their family physician as a source of knowledge or information on CAM therapy.

Fourteen of 76 study participants reported using NST (18\%). The most common NST therapies reported by HCV patients included: prayer, used by four (29\%); meditation, used by eight (57\%); and acupuncture, used by eight (57\%).

\section{Predictors for use of CAM therapies}

Multivariate stepwise regression was carried out to see if patients using CAM therapy or herbal remedies had any common independent predictors. CAM use was independently associated only with serum albumin and level of education. However, when entered into a logistic regression equation, neither of those factors were significant (Table 3). This may be due to the broad spectrum of interventions defined as CAM.

On the other hand, use of herbal therapies was independently associated with the presenting complaint of headache, higher education level, and absence of arthralgia and anorexia. Table 3 shows that headache is a presenting symptom and higher level of education were the only statistically significant factors that predicted herbal supplement use.

\section{DISCUSSION}

In our study of $76 \mathrm{HCV}$ patients, we found that a total of $46 \%$ were using CAM therapies. This was probably a conservative estimation of the real extent of CAM use by patients infected with HCV because past use of CAM therapies was not evaluated.

It is difficult to compare rates of CAM use among studies, because different definitions of CAM are used. Some may disagree with the inclusion of vitamins, while others may argue against inclusion of exercise and prayer (18). In spite of this limitation, a Canadian study from Calgary (19) looking at IBD found that the most common therapies used by patients were vitamin products, herbs and dietary manipulations. We found similar results, with vitamins being used the most often at $28 \%$, followed by herbal therapies at $24 \%$ and NST at $18 \%$.

Our study was conducted on a specialty clinic population. Previously published studies regarding CAM use also recruited their patients from those attending specialty clinics (18-20). It is unclear if seeking medical attention changes patient perception or behaviour regarding CAM use. Patients attending HCV clinics are usually there because they have active disease, see potential benefit from conventional medicine and are comfortable within a conventional medicine framework (3). To avoid these drawbacks, other studies have assessed CAM use in selected patient populations by using large mail-out surveys (21) or Internet questionnaires (3). These methods allow broader sampling of patients and may be a desirable structure for conducting future investigations into CAM use for HCV. In spite of the present study's limitations, conclusions from those large general population-based surveys found similar rates of use $(61.2 \%$ use of herbal therapies over a 12 -month period) (21).

CAM is perceived by users to be beneficial, safe and without side effects, thus giving justification for patients to use it (3). Therefore, it is not surprising that adverse effects were rarely reported. However, CAM therapies can have significant interactions with deleterious effects. Herbal supplements such as garlic, ginkgo and ginseng can interfere with coagulation processes and therefore increase bleeding times (22-24). Because serious bleeding events have been reported (25), patients undergoing invasive disease interventions, such as surgery or liver biopsy, may risk the possibility of excessive bleeding or hemorrhage. In the present study, four of 18 patients (22\%) taking herbal therapies were on herbs that increased bleeding time (two on ginseng, one on Ginkgo biloba and one on garlic pills). Patients need to be questioned about their use of herbal therapies before invasive procedures.

There are additional benefits for inquiring about CAM use. CAM use may indicate a patient's desire for increased control and treatment as a 'whole person' rather than as having a 'diseased organ' (26). This is an important concept for conventional health care providers caring for patients with chronic diseases (3).

\section{Benefits of CAM therapies in liver disease and HCV}

Many alternative therapies are used to treat liver disease; however, none of these therapies have proven to work in all cases (27). Silymarin, extracted from the milk thistle, is the most widely subscribed remedy for liver disease and HCV. Previous studies reported its benefit for patients with alcohol-related cirrhosis (28). Only rare cases of gastrointestinal disturbances and allergic skin rashes have been reported (29).

Silymarin may have a role in the treatment of HCV in combination with alpha-interferon (30). Perceived benefits from CAM therapy include more energy and reduction in fatigue, as well as 'positive effects' on the immune system. In a systematic review (30), 27 eligible randomized clinical trials were located involving herbal products and supplements for patients with HCV. In 14 of the trials, patients received interferon in combination with the complementary therapy. Compared with the control group, significant improvements 
in virological and/or biochemical response were seen in trials of vitamin E, thyme extract, zinc, traditional Chinese medicine (with acupuncture), Glycyrrhiza glabra (licorice root extract) and oxymatrine (30).

Glycyrrhizin has also been shown to reduce and normalize liver enzymes, while St John's wort and ginger decrease side effects from interferon therapy (29). Yet another paper (31) concluded that based on current evidence, the use of herbal supplements for the routine treatment of any chronic liver disease could not be recommended and that further welldesigned clinical trials are necessary. An extensive review (32) concluded that there is no firm evidence of efficacy of any medicinal herbs used to treat HCV infection. In our own practice, use of CAM is not discouraged as long as the intervention is safe, inexpensive and helpful in achieving clinical objectives such as adherence to antiviral therapy for HCV.

\section{Predictors of CAM use}

Patients often do not disclose use of CAM to their medical practitioners because of concerns about a possible negative response by the practitioners, the belief that the practitioner did not need to know about their CAM use and the fact that their practitioner did not ask (6).

Knowing predictors of CAM use may be helpful in alerting physicians to inquire about CAM use. Based on our study, a higher education level was the only predictor for use of CAM and herbal remedies. This finding is similar to other studies that specifically looked into predictors of CAM use. A Spanish study (15) identified sex (women), higher education, and being divorced or widowed as major predictors for use of CAM. In a North American study (14), CAM use was associated with being young and not retired, and was associated with perceived rewards. The study also found the commonly used therapies depended on the geographical location of the patient, the education level, sex, age and the disease the patient was trying to treat as well available services and cultural influences.

\section{CONCLUSION}

The goal of the present study was to identify what CAM therapies patients infected with HCV were using. It is well known from surveys of the general population that CAM use is common and that patients generally combine CAM with conventional medicine rather than abandoning conventional therapy in favour of CAM (2,33). Based on our study of selected populations infected with $\mathrm{HCV}$, we confirmed the prevalent use of CAM. Health care providers should regularly ask patients about CAM use.

ACKNOWLEDGEMENTS: The authors thank the patients from the Liver Clinic, Hepatology Services who participated in the study, and Karen Bonnar, clinic nurse, who orchestrates the movement of patients, families, trainees, nurses and physicians along the long and narrow hallway of the Digestive Diseases Clinic.

\section{APPENDIX: COMPLEMENTARY AND ALTERNATIVE MEDICINE QUESTIONNAIRE}

Please fill in or check blank for response:

1. Identifying number:

2. Age (yrs):

3. Gender:

$\square$ Male

4. Education level:

$\square$ Female

5. Annual household income:

High School

$\square$ Post Secondary

$\square$ Less than $\$ 15,000$

$\square \$ 30,000$ to $\$ 44,999$

$\square \$ 45,000$ to $\$ 75,000$ $\square$ College or University

$\square \$ 15,000$ to $\$ 29,999$

$\square$ greater than $\$ 75,000$

6. Current prescription medications for conditions other than HCV infection:

1.

3.

5.
2.

4.

6.

7. Year HCV first diagnosed:

8. Stage of disease on liver biopsy as per METAVIR system:

$\begin{array}{ll}\square \text { Stage } 0 \text { (no fibrosis) } & \square \text { Stage } 1 \\ \square \text { Stage } 3 & \square \text { Stage } 4 \text { (cirrhosis) }\end{array}$

9. Symptoms reported by HCV infected patient (Check all that apply): $\square$ Arthralgia

$\square$ Fatigue $\square$ Headache

Right Upper

10. Current therapy for HCV:

$\square$ Pegylated interferon
Myalgia

Ribavirin

$\square$ Others: biopsy not done

$\square$ Stage 2

Anorexia

$\square$ Irritability

$\square$ Nausea

$\square$ Interferon 
11. List vitamins/minerals currently taking:

12. Duration taking vitamins/minerals (months):

13. List herbal therapies (Check all that apply):
$\square$ Echinacea
$\square$ Ginseng
$\square$ Milk Thistle
$\square$ Evening primrose oil
$\square$ Glucosamine Sulphate
$\square$ Others:

$\square$ Dandelion root

$\square$ Ginkgo biloba

$\square$ Licorice

14. Duration taking herbal therapies (months):

15. List natural/self therapies (Check all that apply):

Acupuncture

$\begin{array}{ll}\square \text { Aromatherapy } & \square \text { Massage } \\ \square \text { Prayer } & \square \text { Others: }\end{array}$

$\square$ Meditation

16. Duration receiving natural/self therapies (months):

17. Main source of herbal therapy: $\square$ Alternative therapy practitioner

$\square$ Pharmacy or Grocery Store $\square$ Others:

19. Main source of knowledge of herbal therapy:

$\square$ Alternative therapy practitioner

$\square$ Websites $\quad \square$ Books

$\square$ Others:

20. Satisfaction with CAM therapy:

$\square$ Really Worse

$\square$ Unchanged

Better

Nutrient supply store

$\square$ Medical practitioner

21. Cost of CAM therapy:

$\square$ May Be Worse

$\square$ Significantly Better

\section{$\square$ Greater than $\$ 100$ \\ Less than \$50/month \\ Greater than $\$ 100$}

\section{REFERENCES}

1. Ganguli SC, Cawdron R, Irvine EJ. Alternative medicine use by Canadian ambulatory gastroenterology patients: Secular trend or epidemic? Am J Gastroenterol 2004;99:319-26.

2. Eisenberg DM, Davis RB, Ettner SL, et al. Trends in alternative medicine use in the United States, 1990-1997: Results of a followup national survey. JAMA 1998;280:1569-75.

3. Hilsden RJ, Verhoef MJ, Best A, Pocobelli G. Complementary and alternative medicine use by Canadian patients with inflammatory bowel disease: Results from a national survey. Am J Gastroenterol 2003;98:1563-8.

4. Sinclair A. Herbal medicine's on-the-net garden grows. CMAJ 2001;165:1378.

5. Al-Windi A. Determinants of complementary alternative medicine (CAM) use. Complement Ther Med 2004;12:99-111.

6. Robinson A, McGrail MR. Disclosure of CAM use to medical practitioners: A review of qualitative and quantitative studies. Complement Ther Med 2004;12:90-8.

7. Schiano TD. Hepatotoxicity and complementary and alternative medicines. Clin Liver Dis 2003;7:453-73.

8. Shekelle PG, Morton SC, Suttorp MJ, Buscemi N, Friesen C. Challenges in systematic reviews of complementary and alternative medicine topics. Ann Intern Med 2005;142:1042-7.

9. Monti DA, Yang J. Complementary medicine in chronic cancer care. Semin Oncol 2005;32:225-31.

10. Werneke U. A guide to using complementary alternative medicines in cancer. Nurs Times 2005;101:32-5.

11. Strader DB, Bacon BR, Lindsay KL, et al. Use of complementary and alternative medicine in patients with liver disease. Am J Gastroenterol 2002;97:2391-7.

12. Seeff LB, Lindsay KL, Bacon BR, Kresina TF, Hoofnagle JH. Complementary and alternative medicine in chronic liver disease. Hepatology 2001;34:595-603.
13. Giese LA. A study of alternative health care use for gastrointestinal disorders. Gastroenterol Nurs 2000;23:19-27.

14. Bruguera M, Barrera JM, Ampurdanes S, Forns X, Sánchez Tapias JM. Use of complementary and alternative medicine in patients with chronic hepatitis C. Med Clin (Barc) 2004;122(9):334-5.

15. Yang ZC, Yang SH, Yang SS, Chen DS. A hospital-based study on the use of alternative medicine in patients with chronic liver and gastrointestinal diseases. Am J Chin Med 2002;30:637-43.

16. Patrick L. Hepatitis C: Epidemiology and review of complementary/alternative medicine treatments. Altern Med Rev 1999;4:220-38.

17. Lang CA, Conrad S, Garrett L, et al. Symptom prevalence and clustering of symptoms in people living with chronic hepatitis $\mathrm{C}$ infection. J Pain Symptom Manage 2006;31:335-44.

18. Rawsthorne P, Shanahan F, Cronin NC, et al. An international survey of the use and attitudes regarding alternative medicine by patients with inflammatory bowel disease. Am J Gastroenterol 1999;94:1298-303.

19. Hilsden RJ, Scott CM, Verhoef MJ. Complementary medicine use by patients with inflammatory bowel disease. Am J Gastroenterol 1998;93:697-701.

20. Moser G, Tillinger W, Sachs G, et al. Relationship between the use of unconventional therapies and disease-related concerns: A study of patients with inflammatory bowel disease. J Psychosom Res 1996;40:503-9.

21. Harnack LJ, Rydell SA, Stang J. Prevalence of use of herbal products by adults in the Minneapolis/St Paul, Minn, metropolitan area. Mayo Clin Proc 2001;76:688-94.

22. Kohler S, Funk P, Kieser M. Influence of a 7-day treatment with Ginkgo biloba special extract EGb 761 on bleeding time and coagulation: A randomized, placebo-controlled, double-blind 
study in healthy volunteers. Blood Coagul Fibrinolysis 2004;15:303-9.

23. Basila D, Yuan CS. Effects of dietary supplements on coagulation and platelet function. Thromb Res 2005;117:49-53.

24. Dinehart SM, Henry L. Dietary supplements: Altered coagulation and effects on bruising. Dermatol Surg 2005;31:819-26.

25. Bent S, Goldberg H, Padula A, Avins AL. Spontaneous bleeding associated with Ginkgo biloba: A case report and systematic review of the literature. J Gen Intern Med 2005;20:657-61.

26. Cupp MJ. Herbal remedies: Adverse effects and drug interactions. Am Fam Phys 1999;59:1239-45.

27. Cohen MR. Herbal and complementary and alternative medicine therapies for liver disease. A focus on Chinese traditional medicine in hepatitis C virus. Clin Liver Dis 2001;5:461-78,vii.
28. Saller R, Meier R, Brignoli R. The use of silymarin in the treatment of liver diseases. Drugs 2001;61:2035-63.

29. Bean $P$. The use of alternative medicine in the treatment of hepatitis C. Am Clin Lab 2002;21:19-21.

30. Coon JT, Ernst E. Complementary and alternative therapies in the treatment of chronic hepatitis C: A systematic review. J Hepatol 2004:40:491-500.

31. Levy C, Seeff LD, Lindor KD. Use of herbal supplements for chronic liver disease. Clin Gastroenterol Hepatol 2004;2:947-56.

32. Liu JP, Manheimer E, Tsutani K, Gluud C. Medicinal herbs for hepatitis C virus infection. Cochrane Database Sys Rev 2001;CD003183.

33. Astin JA. Why patients use alternative medicine: Results of a national study. JAMA 1998;279:1548-53. 


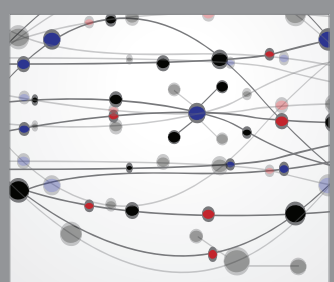

The Scientific World Journal
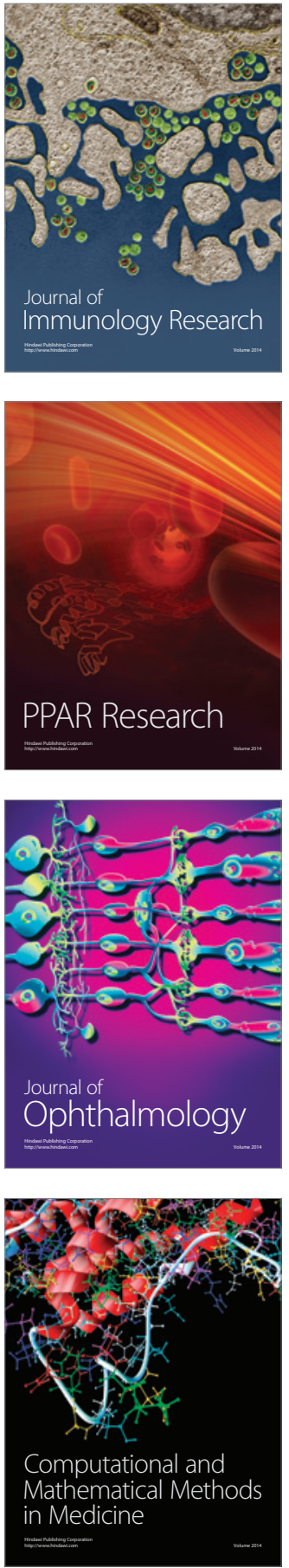

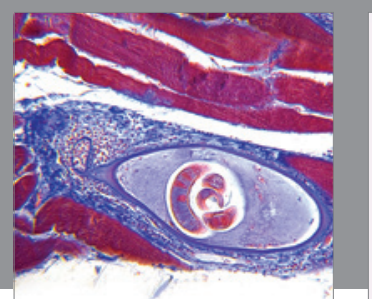

Gastroenterology Research and Practice

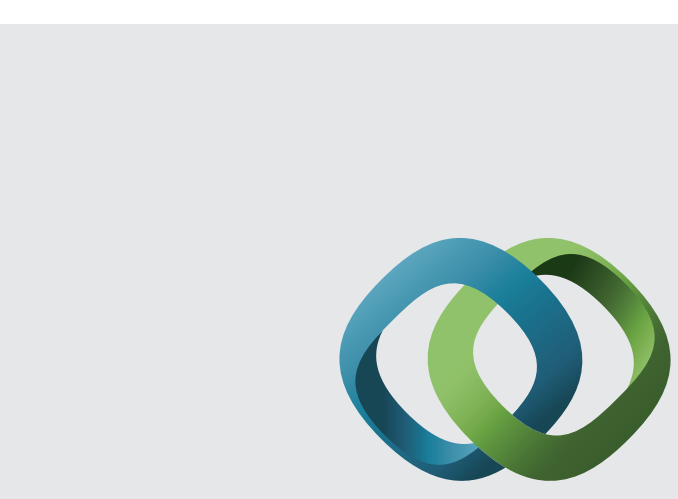

\section{Hindawi}

Submit your manuscripts at

http://www.hindawi.com
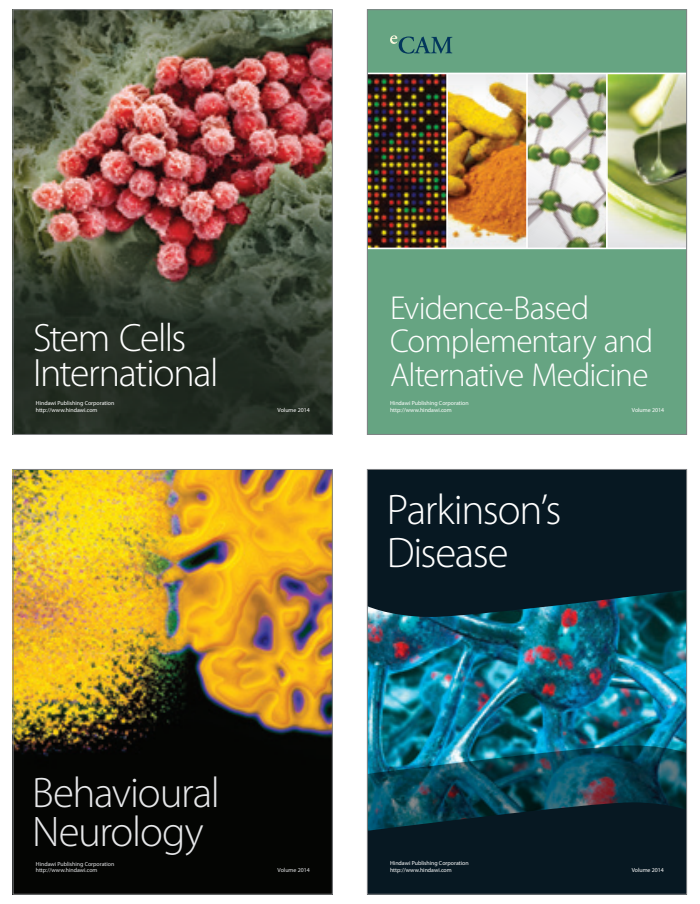
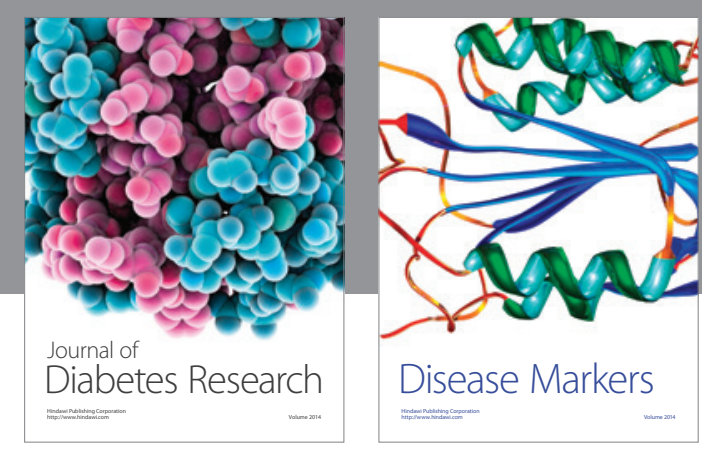

Disease Markers
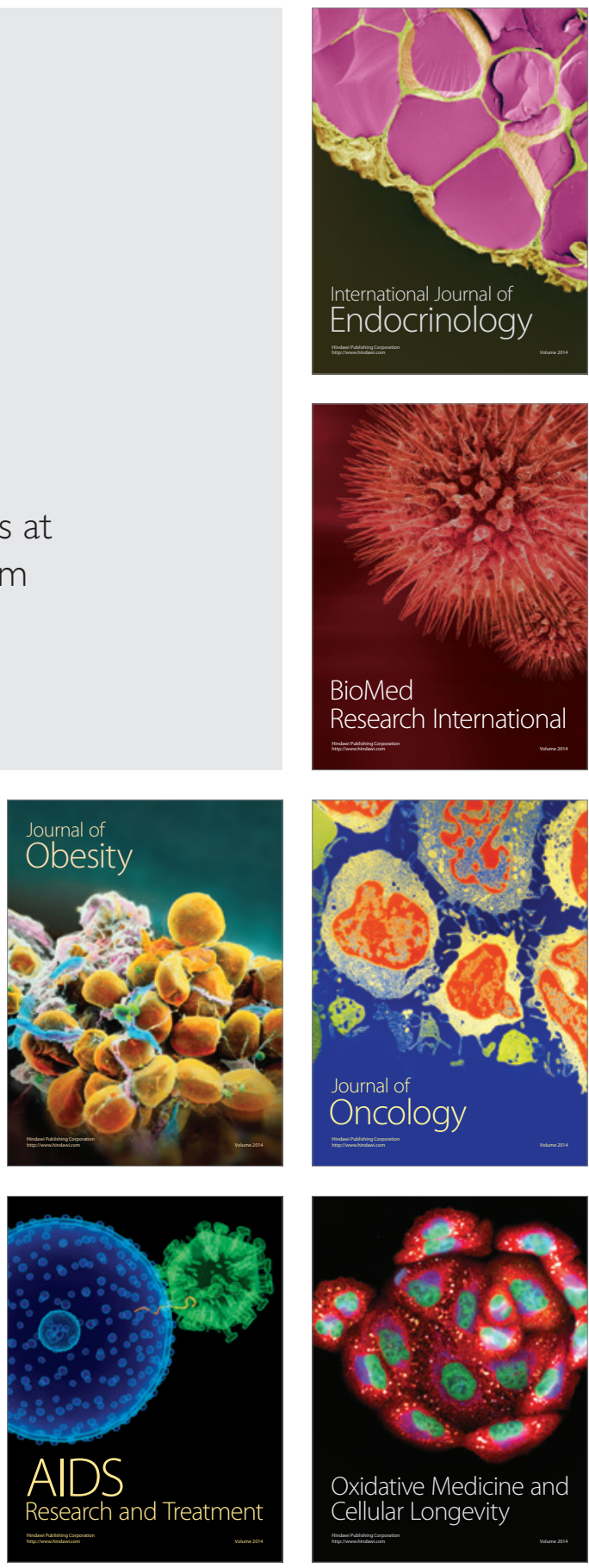